\title{
EFFECT OF DIFFERENT PROBIOTIC BACTERIA ON SURVIVAL RATE, GROWTH, AND PRODUCTION OF WHITELEG SHRIMP IN TRADITIONAL-PLUS TECHNOLOGY
}

\author{
Muharijadi Atmomarsono ${ }^{\#}$ and Endang Susianingsih \\ Research and Development Institute for Coastal Aquaculture
}

(Received 26 September 2014; Final revised 10 February 2015; Accepted 8 June 2015)

\begin{abstract}
Instead of culturing tiger shrimp that is frequently burdened by mass mortality, whiteleg shrimp (Litopenaeus vannamei) is then considered as an alternative commodity in Indonesian brackishwater ponds. To prevent the whiteleg shrimp from diseases, different probiotic bacteria were tested in completely randomized design experiment using nine 250- $\mathrm{m}^{2}$ experimental ponds stocked with 10 PLs of whiteleg shrimp fry $/ \mathrm{m}^{2}$. Three treatments were applied, namely A) alternate use of probiotic bacteria RICA-1, RICA-2, RICA-3; B) alternate use of probiotic bacteria RICA-4, RICA-5, RICA-3, and C) control (without probiotic bacteria); each with three replications. After 11-week application, the results showed that the best survival rate of whiteleg shrimp was achieved by treatment B $(98.83 \%)$ and the best production was achieved by treatment A ( 23.52 $\left.\mathrm{kg} / 250 \mathrm{~m}^{2}\right)$. However, there were no significant differences $(\mathrm{P}>0.05)$ among the three treatments tested for the shrimp survival rate. The whiteleg shrimp production in treatment A and B were signicantly better $(\mathrm{P}<0.05)$ than that in treatment $\mathrm{C}$ (control). These high shrimp production in treatment $\mathrm{A}$ and $\mathrm{B}$ were mainly caused by the capability of the applied probiotics in controlling some water quality variables and Vibrio numbers.
\end{abstract}

KEYWORDS: probiotic bacteria, prevention, whiteleg shrimp, production

\section{INTRODUCTION}

As an alternative commodity, white whiteleg shrimp (Litopenaeus vannamei) is potentially developed in Indonesia brackishwater ponds. Compared to tiger shrimp, whiteleg shrimp grows faster, can live in the whole water column, more productive, and relatively resistant to unbalance water quality. Whiteleg shrimp can be stocked in smaller size (PL-7), higher stocking density with relatively higher survival rate than tiger shrimp (Anonim, 2003; Poernomo, 2004).

High stocking density of the shrimp fry makes new problem in water quality deterioration that enhances shrimp diseases and finally decreasing brackishwater pond productivity. Vibriosis is the main cause of high mortality in larval stages of penaeid shrimp in the hatchery. Generally, vibriosis in the shrimp is mainly caused by one or some strains of pathogenic vibrios like Vibrio alginolyticus, V. harveyi, V. parahaemolyticus, V. damsela, V. vulnificus, V. penaecida, and $V$. fischeri (Lightner et al., 1992; Pasharawipas et al., 1998; Ruangpan, 1998).

\# Corresponding: Research and Development Institute for Coastal Aquaculture. Jl. Makmur Dg. Sitakka No. 129, Maros 90512, South Sulawesi, Indonesia. Tel.: + (0411) 371544/5; E-mail: hari_atmo@yahoo.com
To solve shrimp disease problems, some researches had been done in many ways, but so far the results were still questionable, like using bacterin, water reservoir and biofilter organisms for wastewater treatment (Muliani et al., 1998; Atmomarsono, 2004; Madeali et al., 2004). In addition, eradication of vibriosis using antibiotics also makes vibrios resistance to certain antibiotic. Thus, the use of probiotic bacteria in the cultured shrimp is considered as the best method for shrimp disease prevention in brackishwater ponds.

Probiotic bacteria is non pathogenic bacteria usually used for protection and inhibiting pathogenic bacteria, organic matter demineralization, and neutralizing of poor water quality (Poernomo, 2004). Probiotic bacteria can be isolated from the sea water, sea sediment, coral, pond sediment, mangrove leaves, and macroalgae (Tjahjadi et al., 1994; Rosa et al., 1997; Haryanti et al., 2000; Muliani et al., 2003; 2004; Atmomarsono et al., 2009; Tampangallo et al., 2013).

Some benefits of using probiotic bacteria are 1) safer than chemicals; 2) not pathogen to fish and shrimp; 3) unaccumulated in the foodchain; 4) easily reproduced; 5) not making resistant to pathogenic 
vibrios; 6) potentially used simultaneously with other methods of the shrimp prevention. Probiotics like Bacillus sp., Bacillus subtilis, Lactobacillus spp., Brevibacillus sp., Pseudomonas sp., Pseudoalteromonas sp., Pseudomonas aeruginosa, Vibrio alginolyticus, and Vibrio carchariae have been used in rearing of crab larvae (Nogami \& Maeda, 1992), swimming crab larvae (Susanto et al., 2005), brine shrimp (Villamil et al., 2003), and rainbow trout (Brunt \& Austin, 2005; Brunt et al., 2007). Probiotic bacteria have also been used for tiger shrimp culture (Meunpol et al., 2003; Gunarto et al., 2006; Atmomarsono, 2008; Atmomarsono et al., 2009).

Different kinds of probiotics, its doses, and how the farmers apply are important to achieve the best results. Since 2006 BPPBAP (Balai Penelitian dan Pengembangan Budidaya Air Payau) has developed some probiotic bacteria isolated from brackishwater ponds, mangrove leaves, sea sediment, and macroalgae that are currently called as RICA (Research Institute for Coastal Aquaculture) probiotics. Specifically, RICA-1 is used for controlling total oganic matter and $\mathrm{H}_{2} \mathrm{~S}$ in the shrimp pond water (Muliani et al., 2006; Atmomarsono et al., 2009). RICA-2 and RICA-4 are used for balancing nitrite and nitrate in the shrimp pond water (Muliani et al., 2004) and enhancing the shrimp growth (Atmomarsono et al., 2009; Tampangallo et al., 2013). RICA-3 is Pseudoalteromonas sp. Edeep-1 that has role for decreasing nitrite and controlling Vibrio spp. in the shrimp pond water (Muliani et al., 2003; 2005; Susianingsih et al., 2012a; 2012b; Atmomarsono \& Susianingsih, 2013). RICA-5 is Bacillus licheniformis that has role for controlling ammonia and nitrite in the pond water (Tampangallo et al., 2013). However, to enhance all the above processes, additional oxygen is needed, since the above bacteria are considered as aerobic bacteria which need oxygen for their growth.

The use of different kinds of probiotic bacteria either in different combination or different species alternately used may affect to the growth, production, and survival rate of the cultured shrimp. Thus, this experiment is aimed at finding out the best alternate use of the RICA probiotics for survival rate, growth, and production of the whiteleg shrimp (Litopenaeus vannamei) in brackishwater ponds with traditional-plus technology using supercharge blower as oxygen supplier.

\section{MATERIALS AND METHODS}

This research was conducted at the Marana Experimental Ponds of the Research and Development Institute for Coastal Aquaculture (RICA), Maros using nine $250-\mathrm{m}^{2}$ ponds aerated with supercharge blower.
Each pond was stocked with 10 pcs of PL-8 whiteleg shrimp fry $/ \mathrm{m}^{2}$ that is negative WSSV (tested with PCR machine and IQ2000 test kit). Completely Randomized Design (CRD) with three treatments and three replications each were applied in this experiment. Three treatments tested here are A) alternate use of probiotic bacteria RICA-1, RICA-2, and RICA-3; B) alternate use of probiotic bacteria RICA-4, RICA-5, and RICA-3; and C) control (without probiotic bacteria). Whiteleg shrimp was fed with pellet decreasingly from $50 \%$ at beginning to $2 \%$ at the end of the culture period of total biomass/day.

Before being used, probiotic bacteria was cultured using $1,000 \mathrm{~g}$ of rice bran; $400 \mathrm{~g}$ of fish meal; $500 \mathrm{~g}$ of molasses; and $100 \mathrm{~g}$ of yeast in $20 \mathrm{~L}$ of brackishwater pond water (Poernomo, 2004). All probiotic bacteria were applied twice a week about $10 \mathrm{mg} / \mathrm{L}$ of 3-d fermented culture of bacteria. Alternate use of bacteria for treatment A and B were done every two weeks until the harvest time (11 weeks). This means that either RICA-1 probiotic in treatment A or RICA-4 probiotic in treatment $B$ were firstly applied four times, then followed by four time applications of either RICA-2 probiotic in treatment A or RICA-5 probiotic in treatment $B$, then followed by four time applications of RICA-3 probiotic in treatment A and $\mathrm{B}$, then followed again by application of the first, second, and third probiotic sequently.

Survival rate, growth, and production of whiteleg shrimp were observed after 11 weeks. Data were then analyzed using analysis of variances (ANOVA) and followed by Least Significant Different method (Steel \& Torrie, 1981).

Total bacterial count (TPC) in the pond water was analyzed using Tryptic Soy Agar (TSA) media, while total vibrio count (TBV) was analyzed using Thiosulphate Citrate Bile-salt Sucrose Agar (TCBSA) media every month (Austin, 1987; Buller, 2004). Data were then calculated, tabulized, and discussed descriptively.

Water quality variables like total organic matter (TOM), ammonia-nitrogen $\left(\mathrm{NH}_{3}-\mathrm{N}\right)$, nitrite-nitrogen $\left(\mathrm{NO}_{2}-\mathrm{N}\right)$, and nitrate-nitrogen $\left(\mathrm{NO}_{3}-\mathrm{N}\right)$ were observed every month (Boyd, 1990; American Public Health Association, 2005). Data were then calculated, figurized, and discussed descriptively.

\section{RESULTS AND DISCUSSIONS}

\section{Survival Rate, Growth, and Production of Whiteleg Shrimp}

Survival rate, growth, and production of whiteleg shrimp after 11 weeks of culture can be seen in Table 1 below. The growth of the whiteleg shrimp in each treatment was shown by its size. 
Table 1. Survival rate, size, and production of whiteleg shrimp reared in traditional plus pond aerated with supercharge blower after 11 weeks of culture period applied with alternate use of different probiotics

\begin{tabular}{|c|c|c|c|}
\hline Treatments & $\begin{array}{c}\text { Mean of survival } \\
\text { rate }(\%)\end{array}$ & $\begin{array}{l}\text { Size of shrimp } \\
\text { (g/pcs) }\end{array}$ & $\begin{array}{l}\text { Mean of production } \\
\left(\mathrm{kg} / 250 \mathrm{~m}^{2}\right)\end{array}$ \\
\hline A & $88.31 \pm 9.89^{\mathrm{a}}$ & $10.68 \pm 0.84^{\mathrm{a}}$ & $23.52 \pm 1.97^{\mathrm{a}}$ \\
\hline B & $98.83 \pm 0.31^{\mathrm{a}}$ & $9.53 \pm 1.08^{\mathrm{ab}}$ & $23.10 \pm 2.72^{\mathrm{a}}$ \\
\hline $\mathrm{C}$ & $88.73 \pm 2.52^{\mathrm{a}}$ & $8.11 \pm 0.44^{\mathrm{b}}$ & $17.97 \pm 0.50^{b}$ \\
\hline
\end{tabular}

A = Alternate use of probiotic RICA-1, RICA-2, and RICA-3; B = Alternate use of probiotic RICA-4, RICA-5, and RICA-3; $\mathrm{C}=$ Control (without probiotic bacteria); Values followed by the same superscript in the same rows mean not significantly different $(\mathrm{P}>0.05)$ among treatments tested.

There were no significant differences $(\mathrm{P}>0.05)$ for survival rate of the whiteleg shrimp after 11 weeks of culture in this experiment. However, survival rate of the shrimp in treatment $B$ (alternate use of probiotic RICA-4, RICA-5, and RICA-3) was relatively higher than those in treatment $A$ and $C$. Whiteleg shrimp production in treatment $A$ (alternate use of probiotic RICA1, RICA-2, and RICA-3) and treatment B (alternate use of probiotic RICA-4, RICA-5, and RICA-3) were significantly better $(\mathrm{P}<0.05)$ than that in control. According to Suprapto (2005), probiotic application in intensive shrimp ponds increases survival rate. In this experiment, application of the RICA probiotics alternately in treatment $A$ or $B$ could increase the shrimp production significantly $(\mathrm{P}<0.05)$, but not significantly increased the shrimp survival rate $(\mathrm{P}>0.05)$. The alternate use of probiotic bacteria could minimize the organic waste in the pond water culture media (Figure 1), and the vibrio numbers (Table 2) as well, so that the whiteleg shrimp in these probiotic-treated ponds could live in better water media than the shrimp in control pond. Verschuera et al. (2000) mentioned that application of probiotic bacteria in the culture media could be used as complement feed for the shrimp or contribute in digestive system in protecting the shrimp from pathogenic bacteria, because probiotic bacteria could release antibacteria like bacteriozyme, lysozyme, protease, siderophore, hydrogen peroxide, and organic acid.

\section{Total Vibrio Count (TBV)}

Total number of Vibrio spp. (TBV) in the whiteleg shrimp culture water media during experiment is shown in Table 2 . At the beginning of the experiment, total vibrio count in treatment $A$ and $B$ were much higher than that in control pond water media. Fortunately, total number of Vibrio spp. in the pond water of treatment $\mathrm{A}$ and $\mathrm{B}$ were decreasing much during the culture period of whiteleg shrimp. TBV in these two treatments using RICA probiotics were only $1.92 \times 10^{2} \mathrm{cfu} / \mathrm{mL}$ and $1.25 \times 10^{2} \mathrm{cfu} / \mathrm{mL}$ for the second sampling respectively for treatment $\mathrm{A}$ and $\mathrm{B}$, while in control was quite high $\left(1.87 \times 10^{3} \mathrm{cfu} / \mathrm{mL}\right)$. TBV in treatment $A$ and $B$ for the third sampling were also lower than that in control (Table 2). This result meant that RICA probiotics used in treatment $A$ and $B$ had significant role in controlling vibrio numbers in the shrimp culture water media. Consequently, the whiteleg shrimps in treatment A and B could grow faster than in treatment $C$ (control). Finally the whiteleg shrimp production in treatment $A$ and $B$ were significantly $(\mathrm{P}<0.05)$ better than that in control. RICA probiotics consist of three different species of bacteria that firstly selected by their capability of controlling Vibrio spp. So that, it is normal when the number of Vibrio spp. in treatment A and B were lower than that in control. According to Atmomarsono et

Table 2. Mean number of total vibrio count (TBV) in the traditional-plus pond waters aerated with supercharge blower during application of alternate use of RICA probiotic bacteria for whiteleg shrimp in Marana Experimental Ponds of the Research and Development Institute for Coastal Aquaculture, Maros

\begin{tabular}{ccc}
\hline Treatments & $\begin{array}{c}\text { Period of } \\
\text { sampling }\end{array}$ & $\begin{array}{c}\text { Mean number of TBV } \\
\left(\mathbf{x ~ 1 \mathbf { ~ } ^ { 2 }} \mathbf{c f u} / \mathbf{m L}\right)\end{array}$ \\
\hline \multirow{2}{*}{$\mathrm{A}$} & 1 & 32.31 \\
& 2 & 1.92 \\
& 3 & 1.09 \\
\hline \multirow{2}{*}{$\mathrm{B}$} & 1 & 25.53 \\
& 2 & 1.25 \\
& 3 & 1.32 \\
\hline \multirow{3}{*}{$\mathrm{C}$} & 1 & 9.66 \\
& 2 & 18.67 \\
\hline
\end{tabular}

A = Alternate use of probiotic RICA-1, RICA-2, and RICA-3; $\mathrm{B}=$ Alternate use of probiotic RICA-4, RICA-5, and RICA-3; C = Control (without probiotic bacteria) 
al. (1993; 2010) total number of Vibrio spp. (TBV) in control pond water for the second sampling $(1.87 \mathrm{x}$ $10^{3} \mathrm{cfu} / \mathrm{mL}$ ) is relatively dangerous to the reared shrimp for long time period especially if pond water quality is getting worse like increasing of total organic matter, ammonia-nitrogen $\left(\mathrm{NH}_{3}-\mathrm{N}\right)$, and nitritenitrogen $\left(\mathrm{NO}_{2}-\mathrm{N}\right)$. It was previously reported by Atmomarsono et al. (1993), that the Vibrio spp. numbers in the reared shrimp pond water should not be over $1 \times 10^{3} \mathrm{cfu} / \mathrm{mL}$ for long time period.

The above result was match with that of reported by Atmomarsono et al. (2009), that appplication of probiotic bacteria that is originated from the sea sediment (RICA-3 = Pseudoalteromonas sp. Edeep-1) could control Vibrio spp. in the culture water media. The use of probiotic bacteria originated from the sea was also reported by Vaseeharan \& Ramasamy (2003) using Bacillus subtilis to control pathogenic Vibrio harveyi. Schulze et al. (2006) reported, that application of Pseudoalteromonas undina that is originated from the sea could alleviate the growth of pathogenic virus and bacteria in fish and shrimp culture ponds. Muliani et al. (2009) also reported, that application of bacteria isolate BT951 (RICA-1) which is originated from brackishwater pond (Brevibacillus laterosporus) also could control the growth of Vibrio spp. in the culture pond water.

In general, the number of this Vibrio spp. count (about $10^{2} \mathrm{cfu} / \mathrm{mL}$ ) is still safe for the cultured shrimp as reported by Olafsen et al. (1993 in Buller, 2004). Oyster will be sick if the Vibrio spp. count in their hemolymph increase to $10^{5} \mathrm{cfu} / \mathrm{mL}$. Moriarty (1997) and Defoirdt (2007) mentioned, that if the Vibrio spp. count in the hemolymph reach $10^{5} \mathrm{cfu} / \mathrm{mL}$, then it is called as "quorum sensing", that is the number of bacteria in the hemolymph that possibly causes the diseases of aquatic animals.

\section{Water Quality}

In natural condition, water quality variables like water $\mathrm{pH}$, temperature, total organic matter (TOM), ammonia-nitrogen $\left(\mathrm{NH}_{3}-\mathrm{N}\right)$, nitrite-nitrogen $\left(\mathrm{NO}_{2}-\mathrm{N}\right)$, and nitrate-nitrogen $\left(\mathrm{NO}_{3}-\mathrm{N}\right)$ are very important. Organic matter on the pond bottom soil can be used as indicator of the soil fertility. Organic matter in the pond water is also needed by living organisms, but if the concentration of total organic matter is too much, it will enhance the growth of pathogenic organisms like parasite, bacteria, and viruses. So that the amount of organic matter should be maintained at the minimum level as well as ammonia-nitrogen and nitritenitrogen which are considered as toxic substances for the cultured shrimp and fish.

Fluctuation of several water quality variables like total organic matter (TOM), ammonia-nitrogen, nitrite-nitrogen $\left(\mathrm{NO}_{2}-\mathrm{N}\right)$, and nitrate-nitrogen $\left(\mathrm{NO}_{3}-\mathrm{N}\right)$ are described through below figures.

\section{Total Organic Matter (TOM)}

Figure 1 below shows the fluctuation of total organic matter concentration in the cultured shrimp pond water during experiment.

Naturally, total organic matter (TOM) in the body waters consists of three forms, namely soluble, suspended, and coloidal organic matter. Total organic matter in the pond waters during experiment ranged

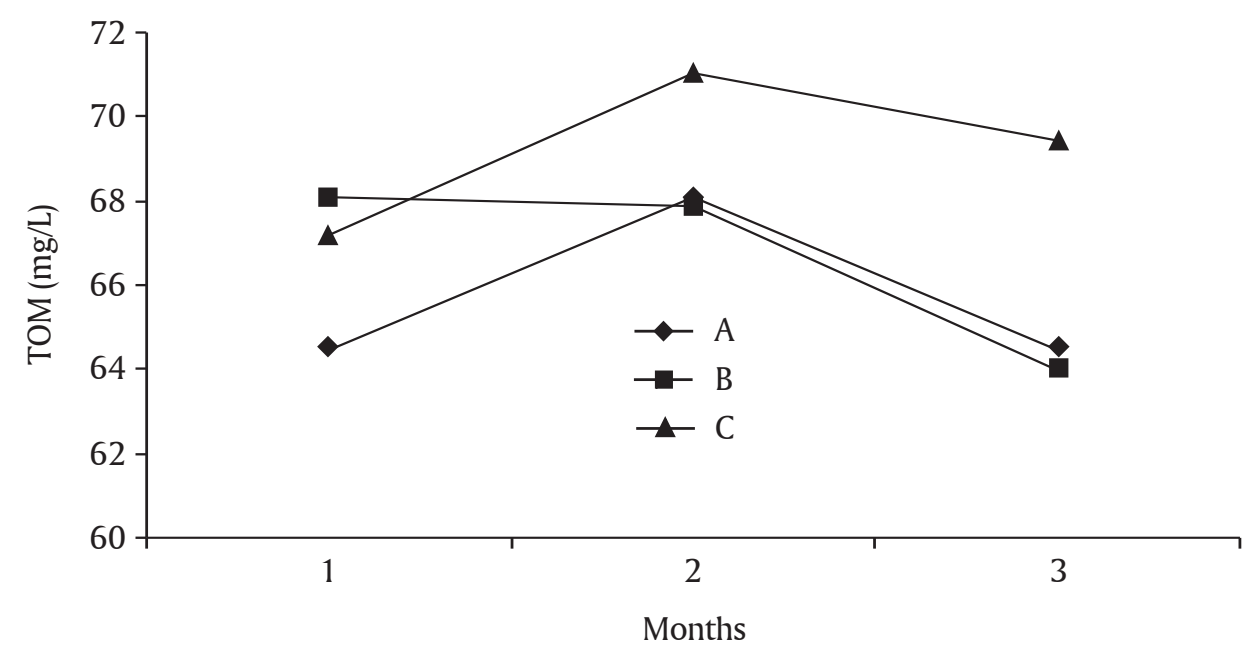

Figure 1. Monthly fluctuation of total organic matter in the culture pond water during experiment on alternately use of RICA probiotics for whiteleg shrimp in traditional-plus technology. $\mathrm{A}=$ Alternate use of probiotic RICA-1, RICA-2, and RICA-3; B = Alternate use of probiotic RICA-4, RICA-5, and RICA-3; C = Control (without probiotic bacteria) 
from 63.99-69.45 mg/L. Generally, concentrations of total organic matter in treatment $\mathrm{C}$ (control) were relatively higher than those in treatment $A$ (alternate use of probiotic RICA-1, RICA-2, and RICA-3) and B (alternate use of probiotic RICA-4, RICA-5, and RICA3) with the average concentration was $69.27 \mathrm{mg} / \mathrm{L}$, followed by treatment $B(66.64 \mathrm{mg} / \mathrm{L})$ and treatment A $(65.65 \mathrm{mg} / \mathrm{L})$. However, these concentrations of total organic matter for the whole pond waters were slightly over than the optimal range for whiteleg shrimp culture (30-60 mg/L).

Feeding for whiteleg shrimp with stocking density of 10 pcs of PL-8 shrimp fry $/ \mathrm{m}^{2}$ will not only increase the shrimp body weight, but also increase total organic matter in the pond water and sediment. Reported by Madeali et al. (2004), that increasing of total organic matter in the shrimp pond water up to 30 $\mathrm{mg} / \mathrm{L}$ could enhance the virulence of Vibrio spp. This might be protected by adding some probiotic bacteria in the pond waters like in treatment $A$ and $B$. In treatment A, the use of probiotic RICA-1 (Brevibacillus laterosporus) could demineralize total organic matter and ammonia-nitrogen as well. This probiotic RICA-1 also could alleviate the growth of Vibrio spp. in the pond water. This condition made the concentration of total organic matter in this treatment was relatively lower than in treatment $\mathrm{B}$ and $\mathrm{C}$ (control). However, the use of pobiotic RICA-4 (Bacillus subtilis) that is originated from seaweed (macroalgae) in treatment $B$ also could control the increase of total organic matter in the pond water.

The high concentration of total organic matter in treatment $\mathrm{C}$ might be caused by not sufficient natu- ral demineralizing bacteria in the pond water. This could enhance the growth of Vibrio spp. (Table 2). Other result reported by Atmomarsono \& Susianingsih (2013), that the alternate use of probiotic bacteria was better than the use of probiotic bacteria combination simultaneously.

\section{Ammonia-Nitrogen $\left(\mathrm{NH}_{3}-\mathrm{N}\right)$}

Ammonia-nitrogen is one of the toxic substances in the shrimp pond water that is more harmfull to the cultured shrimp when the water $\mathrm{pH}$ and salinity increase. So that the concentration of ammonia-nitrogen must be minimized during the culture period. Fluctuation of the average concentration of ammonia-nitrogen $\left(\mathrm{NH}_{3}-\mathrm{N}\right)$ in the vanname shrimp pond waters during experiment could be seen in Figure 2.

The above Figure 2 shows that ammonia-nitrogen $\left(\mathrm{NH}_{3}-\mathrm{N}\right)$ concentration in the shrimp pond water during experiment in treatment A $(0.0946-0.0989 \mathrm{mg} /$ $\mathrm{L})$ and treatment $B(0.1272-0.1608 \mathrm{mg} / \mathrm{L})$ were much lower than in treatment $C(0.1844-0.2818 \mathrm{mg} / \mathrm{L})$. The optimum range of ammonia-nitrogen concentration in the pond water of $L$. vannamei culture by Adiwijaya et al. (2003) is $0.05-0.1 \mathrm{mg} / \mathrm{L}$. Based on this reference, ammonia-nitrogen concentrations in the pond water of treatment $A$ and $B$ were still in good range, while that of in treatment $C$ for the third sampling was quite high. This might cause stress to the whiteleg shrimp, then finally could not grow well (Table 1). Relatively lower concentration of ammonia-nitrogen in treatment $A$ and $B$ up to the third sampling might be caused by the application of probiotic RICA-2 (Serratia marcescens) in treatment A and RICA-5 (Bacillus

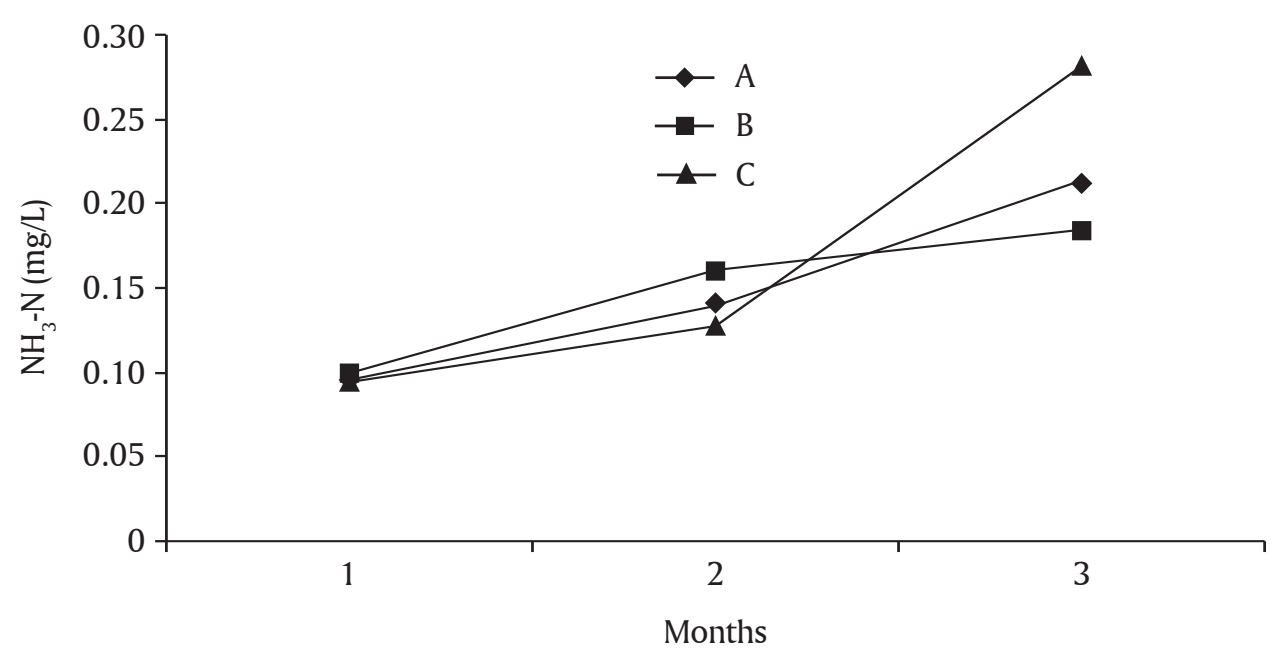

Figure 2. Monthly fluctuation of ammonia-nitrogen $\left(\mathrm{NH}_{3}-\mathrm{N}\right)$ concentration in the whiteleg shrimp pond water during experiment on alternate use of the RICA probiotic bacteria at the Marana Experimental Pond Station. $\mathrm{A}=$ Alternate use of probiotic RICA-1, RICA-2, and RICA-3; B = Alternate use of probiotic RICA-4, RICA-5, and RICA-3; C = Control (without probiotic bacteria) 
licheniformis) in treatment B which are capable of ammonium elimination in the pond water. While the concentration of ammonia-nitrogen in the control pond water $(\mathrm{C})$ was relatively high, because it could not be minimized by natural bacteria in the pond water.

\section{Nitrite-Nitrogen $\left(\mathrm{NO}_{2}-\mathrm{N}\right)$}

Nitrite-nitrogen $\left(\mathrm{NO}_{2}-\mathrm{N}\right)$ is also considered as one of the toxic substances in the cultured shrimp pond water. So that the concentration of this substance in the culture pond water must be controlled strongly. In natural condition the available nitrite-nitrogen in the pond water will be processed to nitrate-nitrogen that is less toxic substance only if nitrification bacteria like Nitrobacter is available enough and under aerobic condition (enough dissolved oxygen). Otherwise this process will not happen that finally makes harmfull to the cultured shrimp. Concentration of nitrite-nitrogen $\left(\mathrm{NO}_{2}-\mathrm{N}\right)$ in the whiteleg shrimp pond waters during experiment could be seen in Figure 3.

The above figure shows that the use of probiotic bacteria seemed to be not effective to decrease concentration of nitrite-nitrogen $\left(\mathrm{NO}_{2}-\mathrm{N}\right)$ in the whiteleg shrimp pond waters. Concentration of nitrite-nitrogen in treatment A ranged from $0.0013-0.0217 \mathrm{mg} / \mathrm{L}$, in treatment B ranged from $0.0011-0.0201 \mathrm{mg} / \mathrm{L}$, and in treatment $C$ ranged from $0.0028-0.0251 \mathrm{mg} / \mathrm{L}$. However, the above concentrations of nitrite-nitrogen for the overall pond waters were still in good range for the cultred shrimp that is much less than $4.5 \mathrm{mg} / \mathrm{L}$ as suggested by (Chen \& Chin, 1998a in Boyd, 1990).

Nitrite-nitrogen is considered as one the immunostressors for the cultured shrimp, so that the con- centration in the pond waters must be minimized as small as possible. Usually this nitrite-nitrogen is affected by concentration of total ammonium nitrogen (TAN) in the pond waters and the available demineralized bacteria naturally. In that case, the additional probiotic bacteria which has ability of neutralizing nitrite-nitrogen will help this process. Adding probiotic bacteria RICA-3 (Pseudoalteromonas sp. Edeep-1) in treatment A and B could not only protect the growth of the pathogenic Vibrio spp., but also neutralize nitrite-nitrogen to become nitrate-nitrogen which is not toxic to the whiteleg shrimp.

\section{Nitrate-Nitrogen $\left(\mathrm{NO}_{3}-\mathrm{N}\right)$}

Fluctuation of nitrate-nitrogen $\left(\mathrm{NO}_{3}-\mathrm{N}\right)$ concentration in the whiteleg shrimp pond waters during experiment could be seen in Figure 4.

Unlike nitrite-nitrogen and ammonia-nitrogen, nitrate-nitrogen is considered as less toxic substance in the pond waters. Nitrate-nitrogen can be used directly by phytoplankton and other algae in the pond waters if ortho-phoshate and other micro nutrients are available in the waters. So that the high concentration of nitrate-nitrogen is not dangerous to the reared whiteleg shrimp. However, to prevent the pond waters from the phytoplankton bloom, concentration of nitrate-nitrogen should be no more than $1.0 \mathrm{mg} / \mathrm{L}$ (Wedemeyer, 1996). So that, if the nitrate-nitrogen concentration of the pond water increases as well as nitrite-nitrogen and ammonia-nitrogen, some molasses or other carbon source should be applied periodically. In this case Atmomarsono (2004) mentioned that C:N:P ratio for the normal growth of usefull phytoplankton should be about 106:16:1. So that in in-

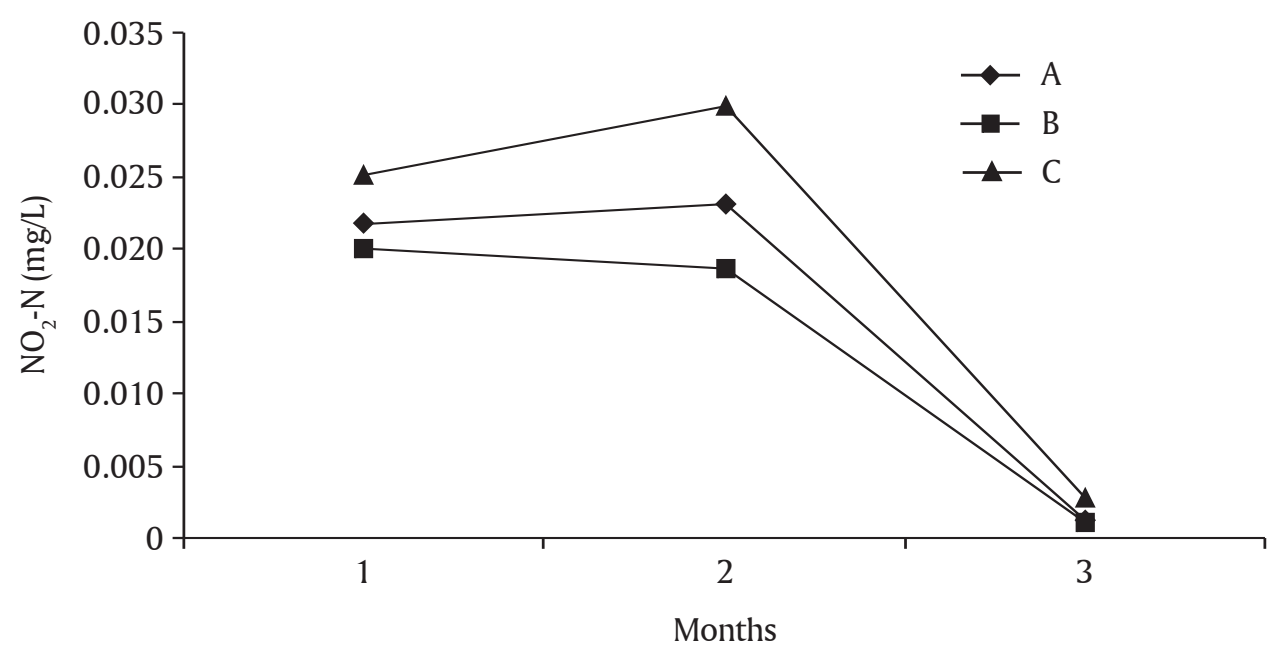

Figure 3. Monthly fluctuation of nitrite-nitrogen $\left(\mathrm{NO}_{2}-\mathrm{N}\right)$ concentration in the whiteleg shrimp pond water during experiment on alternate use of the RICA probiotic bacteria at the Marana Experimental Pond Station. $\mathrm{A}=$ Alternate use of probiotic RICA-1, RICA-2, and RICA-3; B = Alternate use of probiotic RICA-4, RICA-5, and RICA-3; C = Control (without probiotic bacteria) 


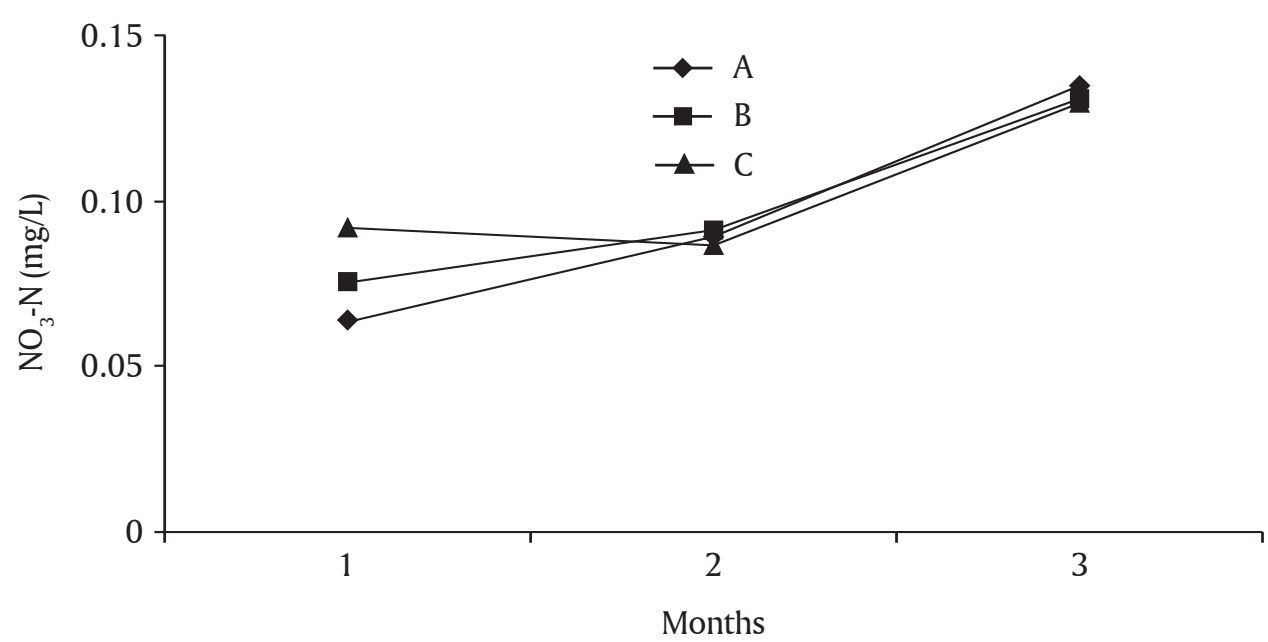

Figure 4. Monthly fluctuation of nitrate-nitrogen $\left(\mathrm{NO}_{3}-\mathrm{N}\right)$ concentration in the whiteleg shrimp pond water during experiment on alternate use of the RICA probiotic bacteria at the Marana Experimental Pond Station. $\mathrm{A}=$ Alternate use of probiotic RICA-1, RICA-2, and RICA-3; B = Alternate use of probiotic RICA-4, RICA-5, and RICA-3; C = Control (without probiotic bacteria)

tensive shrimp pond which uses quite a lot of artificial feed (pellet), some uneaten feed will be demineralized to ammonium and nitrite that finally increases the amount of total nitrogen in the pond water. In this case, some farmers apply molasses or other carbon sources to stabilize the $\mathrm{C}: \mathrm{N}$ ratio in the pond water.

\section{CONCLUSION}

The high survival rate, growth, and production of whiteleg shrimp in this experiment might be related to the use of probiotic bacteria which control total organic matter, ammonia-nitrogen, and the growth of Vibrio spp. in the pond waters.

\section{ACKNOWLEDGEMENTS}

The authors would like to express their appreciation to the Director of the Research and Development Institute for Coastal Aquaculture (RICA) and the Director of the Center for Aquaculture Research and Development for their support in funding this experiment. Their appreciation are also expressed to Ms. Nurbaya, S.Pi., Ms. Nurjanna, S.Pi., and Muh. Rusli for their special role in this experiment, and also to all researchers and technicians in the RICA office who helped them for analysing bacteria, water quality variables, and other activities that make this experiment was smoothly done.

\section{REFERENCES}

Adiwijaya, D., Sapto, P.R., Sutikno, E., Sugeng, \& Subiyanto. (2003). Budidaya udang vaname (Litopenaeus vannamei) sistem tertutup yang ramah lingkungan. Balai Besar Pengembangan Budidaya
Air Payau Jepara. Departemen Kelautan dan Perikanan. Jakarta, 29 pp.

Anonim. (2003). Litopenaeus vannamei sebagai alternatif budidaya udang saat ini. PT Central Proteina Prima (Charoen Pokphand Group) Surabaya, 18 pp.

American Public Health Association (APHA). (2005). Standard methods for the examination of water and wastewater. $21^{\text {th }}$ edition. American Public Health Association. Washington D.C.

Atmomarsono, M. (2004). Pengelolaan kesehatan udang windu, Penaeus monodon di tambak. Aquacultura Indonesiana, 5(2), 73-78.

Atmomarsono, M. (2008). Aplikasi bakteri probiotik dalam budidaya udang di tambak. In Permadi, A., Sipahutar, Y.H., Saifurridjal, Basith, A., Sugriwa, E., Siregar, A.N., Thaib, E.A., Purwanto, \& Sanofa, V. (Eds.). Prosiding Seminar Nasional Perikanan 2008. Pusat Penelitian dan Pengabdian Masyarakat, Sekolah Tinggi Perikanan. Jakarta, p. 441-446.

Atmomarsono, M., Madeali, M.I, Muliani, \& Tompo, A. (1993). Kasus penyakit udang windu di Kabupaten Pinrang. In Hanafi, A., Atmomarsono, M., \& Ismawati, S. (Eds.). Prosiding Seminar Hasil Penelitian Perikanan Budidaya Pantai, Maros. p. 35-40.

Atmomarsono, M., Muliani, \& Nurbaya. (2009). Penggunaan bakteri probiotik dengan komposisi berbeda untuk perbaikan kualitas air dan sintasan pascalarva udang windu. J. Ris. Akuakultur, 4(1), 7383.

Atmomarsono, M., Muliani, \& Tampangallo, B.R. (2010). Aplikasi bakteri probiotik untuk peningkatan sintasan dan produksi udang windu di tambak. In Sudradjat, A., Rachmansyah, Hanafi, A., Azwar, Z. I., Imron, Kristanto, A.H., Chumaidi, \& 
Insan, I. (Eds.). Forum Inovasi Teknologi Akuakultur 2010. Buku I. Pusat Penelitian dan Pengembangan Perikanan Budidaya, Badan Litbang Kelautan dan Perikanan. Jakarta, p. 269-278.

Atmomarsono, M., \& Susianingsih, E. (2013). Tiger shrimp culture in South Sulawesi, Indonesia using local probiotic bacteria. In Sudaryono, A., Hasan, M., \& Budi, G.P. (Eds.). Proceeding International Conference of Aquaculture Indonesia (ICAI) 2012. Indonesian Aquaculture Society. Semarang, p. $110-115$.

Austin, B. (1987). Marine microbiology. Cambridge University Press. Cambridge, 222 pp.

Boyd, C.E. (1990). Water quality in ponds for aquaculture. Birmingham Publishing Co, Birmingham, Alabama. USA, 482 pp.

Brunt, J., \& Austin, B. (2005). Use of a probiotic to control lactococcosis and steptococcosis in rainbow out, Oncorhynchus mykss (Walbaum). Journal of Fish Diseases, 28, 693-701.

Brunt, J., Fyzul, A.N., \& Austin, B. (2007). The development of probiotics for control of multiple bacteria diseases of rainbow trout, Oncorhynchus mykiss (Walbaum). Journal of Fish Diseases, 30, 573579.

Buller, N.B. (2004). Bacteria from fish and other aquatic animals: A practical identification manual. CABI Publishing. Wallingford, Oxfordshire. UK, 361 pp.

Defoirdt, T. (2007). Quorum sensing disruption and the use of short-chain fatty acids and polyhydroxyalkanoates to control luminescent vibriosis. Ph.D. Thesis. Ghent. Ghent University. Belgium, 204 pp.

Gunarto, Tangko, A.M., Tampangallo, B.R., \& Muliani. (2006). Budidaya udang windu (Penaeus monodon) di tambak dengan penambahan probiotik. J. Ris. Akuakultur, 1, 303-313.

Haryanti, Sugama, K., Tsamura, S., \& Nishijima, T. (2000). Vibriostatic bacterium isolated from seawater: Potentiality as probiotic agent in the rearing of Penaeus monodon larvae. Ind. Fish. Res. J., 6, 26-32.

Lightner, D.V., Bell, T.A., Redman, R.M., Mohley, L.L., Natividad, J.M., Rukyani, A., \& Poernomo, A. (1992). A review of some major diseases of economic significance in penaeid prawns/shrimps of the Americas and Indopacific. In Shariff, M., Subasinghe, R.P., \& Arthur, J.R. (Eds.). Diseases in Asian Aquaculture I. Fish Health Section, Asian Fisheries Society, Manila. Philippines, p. 57-80.

Madeali, M.I., Atmomarsono, M., \& Ahdiah, H. (2004). Efektivitas pemberian sel utuh (whole cell) bakteri Vibrio sp. terhadap peningkatan kekebalan tubuh udang windu (Penaeus monodon Fabr.) dari serangan White Spot Syndrome Virus. J. Penelitian Perikanan
Indonesia, edisi Akuakultur, 10(2), 59-70.

Meunpol, O., Lopinyosiri, K., \& Menasveta, P. (2003). The effects of ozone and probiotics on the survival of black tiger shrimp (Penaeus monodon). Aquaculture, 220, 437-448.

Moriarty, D.J.W. (1997). The role of microorganisms in pond aquaculture. Aquaculture, 151, 333-349.

Muliani, Atmomarsono, M., \& Madeali, M.I. (1998). Pengaruh penggunaan kekerangan sebagai biofilter terhadap kelimpahan dan komposisi jenis bakteri pada budidaya udang windu (Penaeus monodon) dengan sistem resirkulasi air. Jurnal Penelitian Perikanan Indonesia, 3, 54-61.

Muliani, Nurbaya, \& Atmomarsono, M. (2006). Penapisan bakteri yang diisolasi dari tambak udang sebagai kandidat probiotik pada budidaya udang windu, Penaeus monodon. J. Ris. Akuakultur, 1, 7385.

Muliani, Nurbaya, \& Madeali, M.I. (2009). Pengaruh pergiliran pemberian bakteri probiotik terhadap kualitas air dan sintasan udang windu (Penaeus monodon) dalam bak terkontrol. hlm. II-316-II-322. Dalam Hardianto, D., Taufiqurrohman, M. (Eds.). Prosiding Seminar Nasional Kelautan V. Universitas Hang Tuah, Surabaya, 23 April 2009. ISBN:978-9793153-61-2.

Muliani, Nurbaya, \& Tompo, A. (2005). Pengaruh jenis dan konsentrasi bakteri probiotik terhadap kualitas air dan sintasan pascalarva udang windu yang dipapar dengan White Spot Syndrome Virus (WSSV). Makalah dipresentasikan pada Seminar Nasional dan Kongres Biologi XIII, Yogyakarta, 16-17 September 2005, 10 pp.

Muliani, Nurbaya, Tompo, A., \& Atmomarsono, M. (2004). Eksplorasi bakteri filoster dari tanaman mangrove sebagai bakteri probiotik pada budidaya udang windu, Penaeus monodon. J. Pen. Perik. Indonesia, 2, 47-57.

Muliani, Suwanto, A., \& Hala, Y. (2003). Isolasi dan karakterisasi bakteri asal laut Sulawesi untuk biokontrol penyakit vibriosis pada larva udang windu (Penaeus monodon Fab.). Hayati, 10, 6-11.

Nogami, K., \& Maeda, M. (1992). Bacteria as biocontrol agents for rearing larvae of the crab Portunus triberculatus. J. Fish. Aquat. Sci., 49, 2373-2376.

Pasharawipas, T., Sriurairatana, S., Direkbusarakom, S., Donayadol, Y., Thaikua, S., Ruangpan, L., \& Flegel, T.W. (1998). Luminous Vibrio harveyi associated with tea brown gill syndrome in black tiger shrimp. p. 213-216. In Flegel, T.W. (Ed.). Advances in shrimp biotechnology. The National Center for Genetic Engineering and Biotechnology, Thailand.

Poernomo, A. (2004). Technology of probiotics to 
solve the problems in shrimp pond culture and the culture environment. Paper presented in The National Symposium on Development and Scientific and Technology Innovation in Aquaculture, January 27-29, 2004. Patrajasa Hotel, Semarang, 25 pp.

Rosa, D., Zafran, Taufik, I., \& Girsang, M.A. (1997). Pengendalian Vibrio harveyi secara biologis pada larva udang windu (Penaeus monodon): I. Isolasi bakteri penghambat. J. Pen. Perik. Indonesia, 3, 110.

Ruangpan, L. (1998). Luminous bacteria associated with shrimp mortality. p. 205-211. In Flegel, T.W. (Ed.). Advances in shrimp biotechnology. The National Center for Genetic Engineering and Biotechnology, Thailand.

Schulze, A.D., Alabi, A.O., Tattersal-Sheldrake, A.R., \& Miller, K.M. (2006). Bacterial diversity in a marine hatchery: Balance between pathogenic and potentially probiotic bacterial strains. Aquaculture, 256, 50-73.

Steel, R.G.D, \& Torrie, J.H. (1981). Principles and procedures of statistics. A biometrical Approach ( $2^{\text {nd }}$ edition). International Student Edition. McGrawHill International Book Company.,633 pp.

Suprapto, B. (2005). Petunjuk teknis budidaya udang vaname (Litopenaeus vannamei). CV. Biotirta. Bandar Lampung, $25 \mathrm{pp}$.

Susanto, B., Setyadi, I., Syahidah, D, Marzuqi, M., \& Rusdi, I. (2005). Penggunaan bakteri probiotik sebagai kontrol biologi dalam produksi massal benih rajungan (Portunus pelagicus). J. Pen. Perik. Indonesia, 11, 15-23.

Susianingsih, E., Nurbaya, \& Atmomarsono, M. (2012a). Pengaruh kombinasi jenis bakteri probiotik berbeda terhadap sintasan dan produksi udang windu di tambak semi-intensif. J. Ris. Akuakultur, 7(8), 489-502.
Susianingsih, E., Nurbaya, \& Atmomarsono, M. (2012b). Sintasan dan produksi udang windu di tambak pada aplikasi bakteri probiotik berbeda. p: RB-13, 1-7. Dalam Isnansetyo, A., Husni, A., Djumanto, Rachmawati, N., Widaningroem, R., Rustadi, Suadi, \& Ustadi (Eds.). Prosiding Seminar Nasional Tahunan IX Hasil Penelitian Perikanan dan Kelautan Tahun 2012. Jurusan Perikanan Fakultas Pertanian, UGM, Yogyakarta.

Tampangallo, B.R., Atmomarsono, M., \& Muliani. (2013). Isolasi dan identifikasi bakteri penghasil enzim amilase, protease, kitin, dan selulose dari makroalga. p. 825-832. Prosiding Forum Inovasi Teknologi Akuakultur. Pusat Penelitian dan Pengembangan Perikanan Budidaya. Jakarta.

Tjahjadi, M.R., Angka, S.L., \& Suwanto, A. (1994). Isolation and evaluation of marine bacteria for biocontrol of luminous bacterial diseases in tiger shrimp larvae (Penaeus monodon Fab.). Aspac. J. Mol. Biol. Biotechnol. 2, 347-352.

Vaseeharan, B., \& Ramasamy, P. (2003). Control of pathogenic Vibrio spp. by Bacillus subtilis BT23, a possible probiotic treatment for black tiger shrimp Penaeus monodon. Lett. Appl. Microbiol., 37, 443447.

Verschuera, L., Rombaut, G., Sorgeloos, P., \& Verstraete, W. (2000). Probiotic bacteria as biological control agents in aquaculture. Mic. Mol. Biol. Rev., 64(4), 655-671.

Villamil, I., Firgueras, A., Planas, M., \& Novon, B. (2003). Control of Vibrio alginolyticus in artemia culture by treatment with bacterial probiotics. Aquaculture, 219, 43-56.

Wedemeyer, G.A. (1996). Physiology of fish in intensive culture systems. Chapman \& Hall. New York, 277 pp. 